\title{
Upconversional Nanoprobe with Highly Efficient Energy Transfer for Ultrasensitive Detection of Alkaline Phosphatase
}

Mengping Gao,a, ${ }^{\mathrm{a}, \dagger}$ Ruiying Wu, ${ }^{\mathrm{b}, \dagger}$ Qingsong Mei, a," Cuilan Zhang, ${ }^{a}$ Xiao Ling, ${ }^{a}$ Shengsong Deng, a, ${ }^{\text {, }}$ Hongbo He $\mathrm{He}^{\mathrm{a}}$ and Yong Zhang $\mathrm{c}^{\mathrm{c}, \mathrm{d}, *}$

a School of Food and Biological Engineering, Hefei University of Technology, Hefei, Anhui 230009, China.

b Department of Traditional Chinese Medicine, The First Affiliated Hospital of University of Science and Technology of China, Hefei, Anhui 230001, China

${ }^{c}$ Department of Biomedical Engineering, Faculty of Engineering, National University of Singapore, Singapore 117575, Singapore

d School of Environmental and Chemical Engineering, Shanghai University, 99 Shangda Road, 200444, Shanghai, China

† These authors contribute equally to this work.

E-mail: qsmei@hfut.edu.cn; buffer119@163.com; biezy@nus.edu.sg 


\section{Experimental section}

\subsection{Materials and characterization}

Oleic acid, octadecene, tris(hydroxymethyl)aminomethane were obtained from Sigma-Aldrich. 4-(2-Hydroxyethyl)-1-piperazineethanesulfonic acid (HEPES), p-nitrophenyl phosphate ( $p$-NPP), alkaline phosphatase from calf intestine (ALP), and 5-sulfosalicylic acid (SA) were obtained from Aladdin. $\mathrm{NaOH}, \mathrm{NH}_{4} \mathrm{~F}, \mathrm{FeCl}_{3}, \mathrm{NaCl}, \mathrm{MgCl}_{2}, \mathrm{NaNO}_{3}, \mathrm{NaNO}_{2}$, $\mathrm{Na}_{2} \mathrm{SO}_{4}, \mathrm{NaHSO}_{4}, \mathrm{Na}_{2} \mathrm{SO}_{3}, \mathrm{Na}_{2} \mathrm{CO}_{3}, \mathrm{NaHCO}_{3}, \mathrm{Na}_{2} \mathrm{HPO}_{4}, \mathrm{NaH}_{2} \mathrm{PO}_{4}$, ethanol, acetic acid, acetone, cyclohexane, and other commonly used solvents were obtained from Sinopharm Chemical Reagent Co., Ltd. (Shanghai, China). All of these reagents were used as received without further purification. $\mathrm{Y}_{2} \mathrm{O}_{3}, \mathrm{Yb}_{2} \mathrm{O}_{3}, \mathrm{Er}_{2} \mathrm{O}_{3}$ were purchased from Aladdin, and further reacted with acetic acid to obtain their acetates as we previously reported protocol.

The morphology of upconversion nanoparticles was characterized by using a transmission electron microscope (TEM, JEOL-2010). UV-vis absorption spectra were recorded by a UV-9000S spectrometer (Shanghai Metash instruments Co., Ltd.). Fluorescence spectra were measured on a LS-55 fluorescence spectrophotometer equipped with a $980 \mathrm{~nm}$ laser

\subsection{Synthesis of upconversion nanoparticles}

The oleate-capped $\mathrm{NaYF}_{4}: 20 \% \mathrm{Yb}, 2 \% \mathrm{Er} @ \mathrm{NaErF}_{4} @ \mathrm{NaYF}_{4}(1$ mmol@0.5 mmol@0.2 mmol) were synthesized through modified seed mediated method. Typically, $212.8 \mathrm{mg}$ $\mathrm{Y}\left(\mathrm{CH}_{3} \mathrm{COO}\right)_{3}, 63 \mathrm{mg} \mathrm{Yb}\left(\mathrm{CH}_{3} \mathrm{COO}\right)_{3}, 6.8 \mathrm{mg} \mathrm{Er}\left(\mathrm{CH}_{3} \mathrm{COO}\right)_{3}$, and $420 \mathrm{mg} \mathrm{NaF}$ were dissolved 
in $10 \mathrm{~mL} \mathrm{OA}$ and $10 \mathrm{~mL}$ ODE in a three-necked flask and degassed to remove residual water and oxygen at $110^{\circ} \mathrm{C}$. Then the mixture was heated to $300{ }^{\circ} \mathrm{C}$ and maintained for $1 \mathrm{~h}$ under nitrogen atmosphere to form a homogeneous solution. While maintaining the temperature at $300{ }^{\circ} \mathrm{C}, 172 \mathrm{mg} \mathrm{Er}\left(\mathrm{CH}_{3} \mathrm{COO}\right)_{3}$ were dissolved in $4 \mathrm{~mL} \mathrm{OA}$ and $4 \mathrm{~mL}$ ODE in another three-necked flask to prepare the first shell precursor, which was then degassed and heated to $200{ }^{\circ} \mathrm{C}$. After the core solution was maintained for $1 \mathrm{~h}$, the shell precursor was injected dropwise into the core solution and maintained at $300{ }^{\circ} \mathrm{C}$ for $1 \mathrm{~h}$ to obtain core-shell nanoparticles. At the same time, $53.2 \mathrm{mg} \mathrm{Y}\left(\mathrm{CH}_{3} \mathrm{COO}\right)_{3}$ were dissolved in $4 \mathrm{~mL}$ OA and $4 \mathrm{~mL}$ ODE in another flask to prepare the second shell precursor and injected into the core-shell solution. The core-shell-shell UCNPs were obtained after further reaction at $300{ }^{\circ} \mathrm{C}$ for $1 \mathrm{~h}$. After the solution was cooled to room temperature, the nanoparticles were precipitated down with acetone and centrifuged. The precipitate was washed with the mixture of cyclohexane and ethanol for three times, and then dispersed in cyclohexane for further use. The core nanoparticle $\mathrm{NaYF}_{4}: 20 \% \mathrm{Yb}, 2 \% \mathrm{Er} \quad(1 \mathrm{mmol})$ and the core-shell nanoparticle $\mathrm{NaYF}_{4}: 20 \% \mathrm{Yb}, 2 \% \mathrm{Er} @ \mathrm{NaErF}_{4}(1 \mathrm{mmol} @ 0.5 \mathrm{mmol})$ were synthesized as the above protocol.

For exfoliation of oleate ligand on the surface of nanoparticles, $15 \mathrm{~mL}$ of the nanoparticles in cyclohexane mixed with $10 \mathrm{~mL}$ of $\mathrm{HCl}$ solution $(0.1 \mathrm{M})$, and stirred for $1 \mathrm{~h}$. After the reaction, the water solution was collected by the separatory funnel, The oleic acid on the surface of UCNPs was removed with diethyl ether, and UCNPs were centrifuged and washed with water for three times, and then re-dispersed in deionized water.

\subsection{Luminescence quenching studies.}

For luminescence quenching measurements, $3 \mu \mathrm{L}$ of the water-dispersible UCNPs (about 
$12 \mathrm{mg} / \mathrm{mL}$ ) was added into $1.8 \mathrm{~mL}$ of HEPES buffer $(\mathrm{pH} 6.0)$ in a quartz cuvette. $2 \mu \mathrm{L}$ of SA-Fe complex solution $(0.1 \mathrm{M})$ was dropped into above solution each time, until $40 \mu \mathrm{L}$ SA-Fe solution were added into the quartz cuvette. Fluorescence intensities were recorded with excitation wavelength of $980 \mathrm{~nm}$ after the reaction time for $10 \mathrm{~min}$.

\subsection{Detections of phosphate ions and ALP.}

For the preparation of nanoprobes, the SA-Fe complex was first mixed and incubated with the UCNP solutions for about 10 minutes. The formed nanoprobes were centrifuged and washed for two times, and re-dispersed in water with the concentration of $20 \mathrm{mg} / \mathrm{mL}$. The attached SA-Fe complex on the surface of UCNPs was estimated to be $2 \mathrm{mM}$ according to the $\mathrm{UV}$-vis absorption spectra. For detection of phosphate ions, $3 \mu \mathrm{L}$ of the water-dispersible nanoprobe was added into $1.8 \mu \mathrm{L}$ of HEPES buffer ( $\mathrm{pH} 6.0$ ), and then different concentration of phosphate ions $\left(10^{-6}-10^{-1} \mathrm{M}\right)$ were added into the above mixture, and incubated for $5 \mathrm{~min}$. The fluorescence spectrum was recorded with excitation wavelength of $980 \mathrm{~nm}$. All measurements were conducted in triplicate at least.

The ALP activity assay was performed with the following procedures. $1 \mathrm{~mL}$ of $0.1 \mathrm{mM}$ p-NPP dispersed in $10 \mathrm{mM}$ Tris- $\mathrm{HCl}$ buffer $\left(\mathrm{pH} 9.8\right.$, including $0.5 \mathrm{mM} \mathrm{MgCl}_{2}$ ) was added into ampoule bottle, and $1 \mathrm{~mL}$ of freshly prepared ALP standard aqueous solution $(2 \mathrm{mU} / \mathrm{mL})$ were added into above solution. The mixture was incubated at $37{ }^{\circ} \mathrm{C}$ for $30 \mathrm{~min}$. ALP catalyzed p-NPP to generate phosphate ions. Different amounts of products solution were then added into the nanoprobe solution for recording the luminescence variations. All measurements were conducted in triplicate at least.

\subsection{Detections of ALP in human serum samples.}


Three human serum samples (labelled as sample A, B, C) were collected from three women volunteers in the First Affiliated Hospital of University of Science and Technology of China. Before the ALP detection, these serum samples were diluted 20 folds with Tris-HCl buffer (10 mM, pH 9.8). The concentration of ALP in these samples was first measured by commercial ELISA kit.

The detection of ALP activity in these serum samples by our proposed method was performed as following procedures. $50 \mu \mathrm{L}$ of p-NPP in Tris- $\mathrm{HCl}$ buffer $(10 \mathrm{mM}, \mathrm{pH} 9.8$, including $0.5 \mathrm{mM} \mathrm{MgCl} 2$ ) with the concentration of $1 \mathrm{mM}$ was mixed with $10 \mu \mathrm{L}$ of the diluted human serum samples and $40 \mu \mathrm{L}$ of buffer. The mixture was then incubated at $37^{\circ} \mathrm{C}$ for $1 \mathrm{~h}$. At last, $20 \mu \mathrm{L}$ of the reactant was added into $2 \mathrm{~mL}$ of nanoprobe solution to measure the luminescence variations. The concentration of ALP in serum was then calculated through the linear relationship which was described in the main text.

\section{Supplementary data}




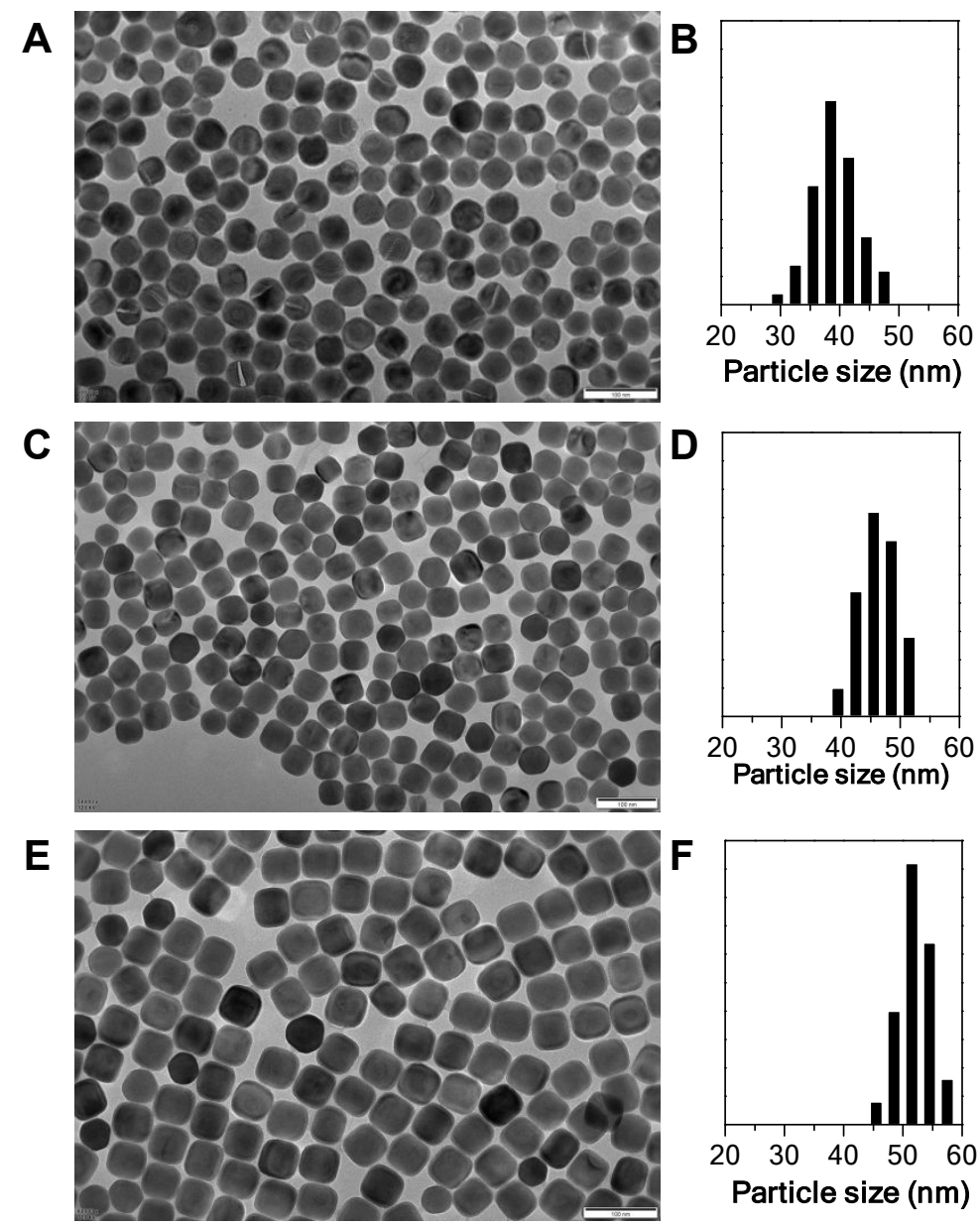

Fig. S1 TEM images and the corresponding particle size distributions of the $\mathrm{NaYF}_{4}: \mathrm{Yb} / \mathrm{Er}(\mathrm{A}$ and B), $\mathrm{NaYF}_{4}: \mathrm{Yb} / \mathrm{Er} @ \mathrm{NaErF}_{4}\left(\mathrm{C}\right.$ and D), $\mathrm{NaYF}_{4}: \mathrm{Yb} / \mathrm{Er} @ \mathrm{NaErF}_{4} @ \mathrm{NaYF}_{4}(\mathrm{E}$ and $\mathrm{F}) . \mathrm{All}$ of the scale bars are $100 \mathrm{~nm}$. 


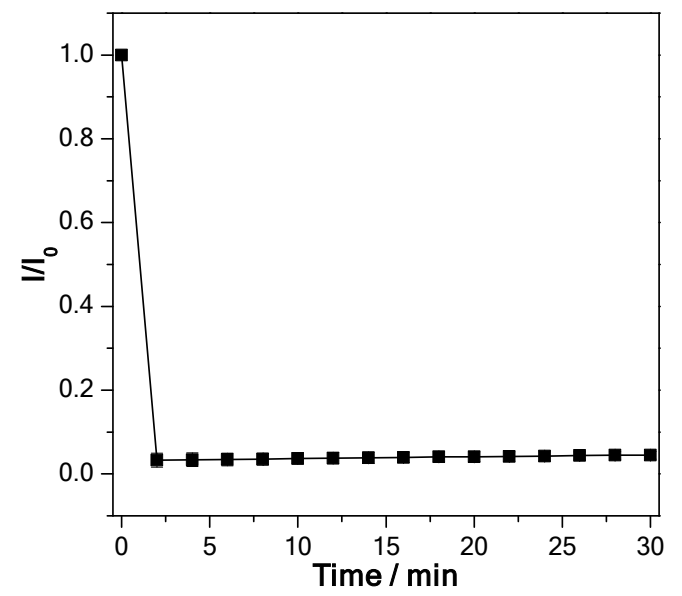

Fig. S2 Luminescence quenching kinetic of the UCNPs after addition of $4 \mathrm{mM}$ of SA-Fe complex in a period of $30 \mathrm{~min}$.

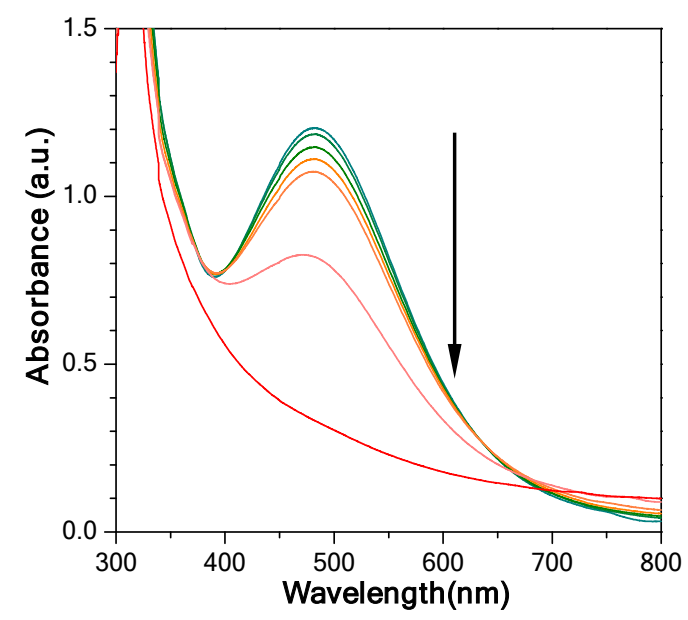

Fig. S3 The absorption spectra of the complex SA-Fe in the present of different concentrations of phosphate ions. From top to bottom, the concentrations are $0,1 \times 10^{-8}$, $1 \times 10^{-7}, 1 \times 10^{-6}, 1 \times 10^{-5}, 1 \times 10^{-4}, 1 \times 10^{-3} \mathrm{M}$. 


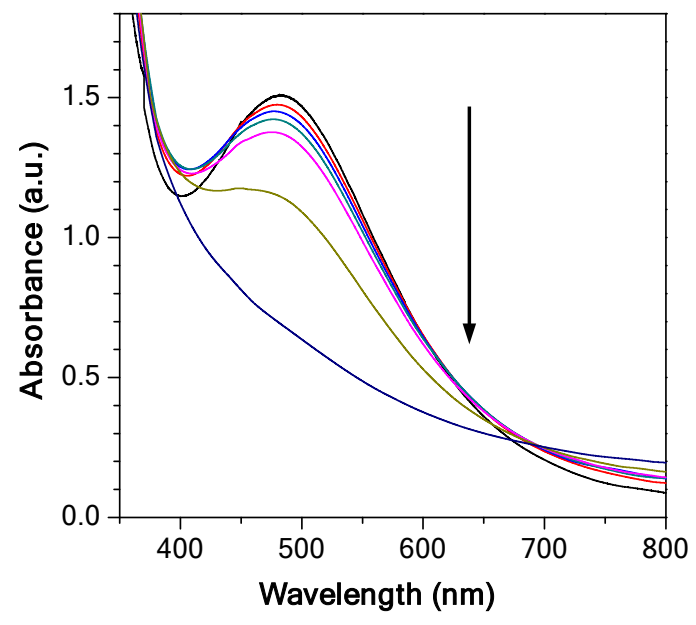

Fig. S4 The absorption spectral variations of the SA-Fe complex modified nanoprobes in the present of different concentrations of phosphate ions. From top to bottom, the concentrations are $0,1 \times 10^{-8}, 1 \times 10^{-7}, 1 \times 10^{-6}, 1 \times 10^{-5}, 1 \times 10^{-4}, 1 \times 10^{-3} \mathrm{M}$.

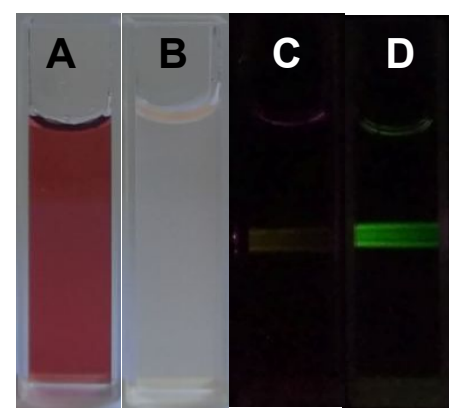

Fig. S5 Photos of the nanoprobe before (A and C) and after (B and D) additions of phosphate ions under natural light (A and B) and under excitation at $980 \mathrm{~nm}(\mathrm{C}$ and $\mathrm{D})$. 


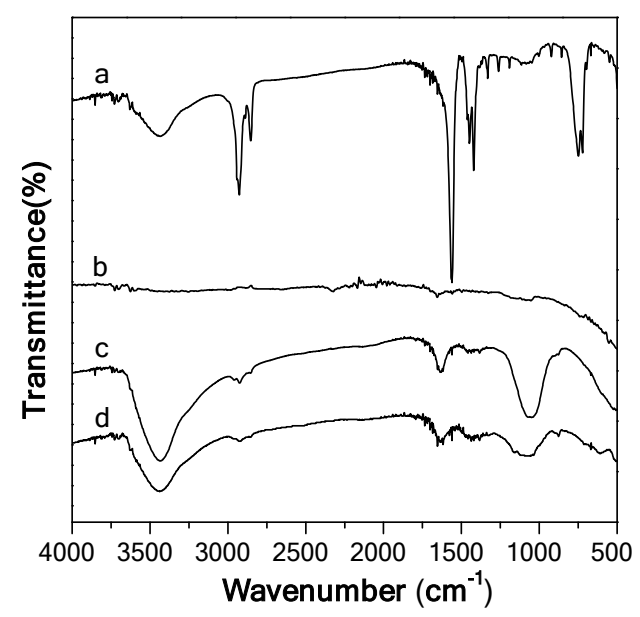

Fig. S6 FTIR spectra of (a) oleate capped UCNPs, (b) ligand-free UCNPs, (c) SA-Fe complex modified UCNPs, and (d) SA-Fe complex modified UCNPs after reacting with phosphate ions.

We have investigated the FTIR spectra of the UCNPs after exfoliation of OA molecules, further conjugation with SA-Fe complex, and displacement of $\mathrm{Fe}^{3+}$. The results in Figure S6a and S6b showed that the sketching vibration band of methylene and carboxyl groups disappeared after exfoliation. After conjugation with SA-Fe complex, the emergence of new band at $1060 \mathrm{~cm}^{-1}$ is attributed to the symmetric stretches of sulfonic acid group, and the band at $1636 \mathrm{~cm}^{-1}$ is attributed to the stretching vibration of carbonyl group in SA. These two bands are retained after displacement of $\mathrm{Fe}^{3+}$, which verifies SA molecules are still conjugated on the surface of UCNPs. 


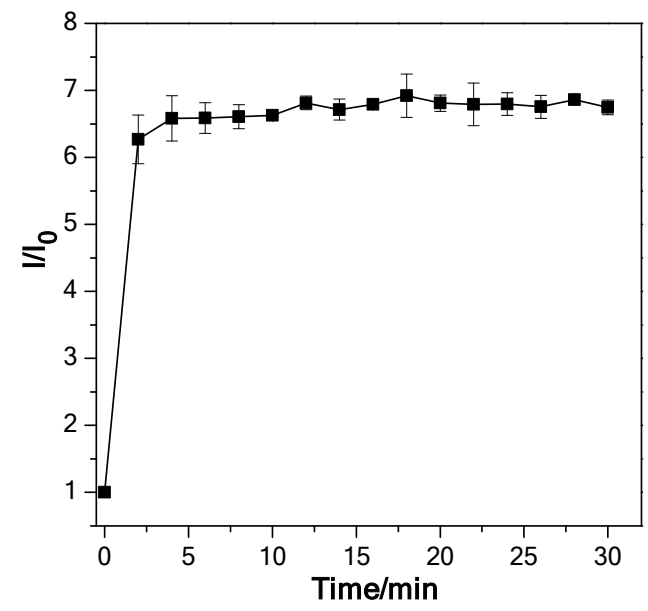

Fig. S7 The luminescence recovery kinetic of the nanoprobe after addition of $1 \mathrm{mM}$ of phosphate ions in a period of $30 \mathrm{~min} . \mathrm{I}_{0}$ and $\mathrm{I}$ are the intensity of the nanoprobe before and after additions of phosphate ions.

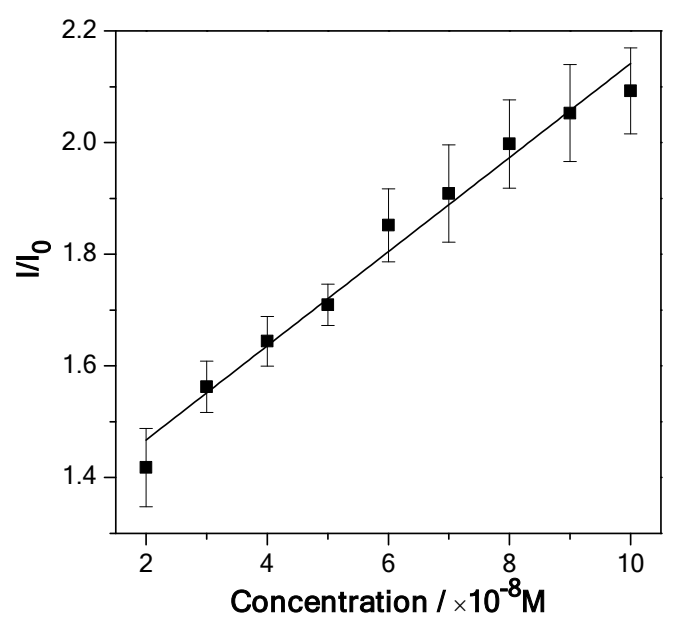

Fig. S8 Linear calibration curve of luminescence enhancement after additions of phosphate ions in the range of $1 \sim 10 \times 10^{-8} \mathrm{M} . \mathrm{I}_{0}$ and $\mathrm{I}$ are the intensity of the nanoprobe before and after additions of phosphate ions. 


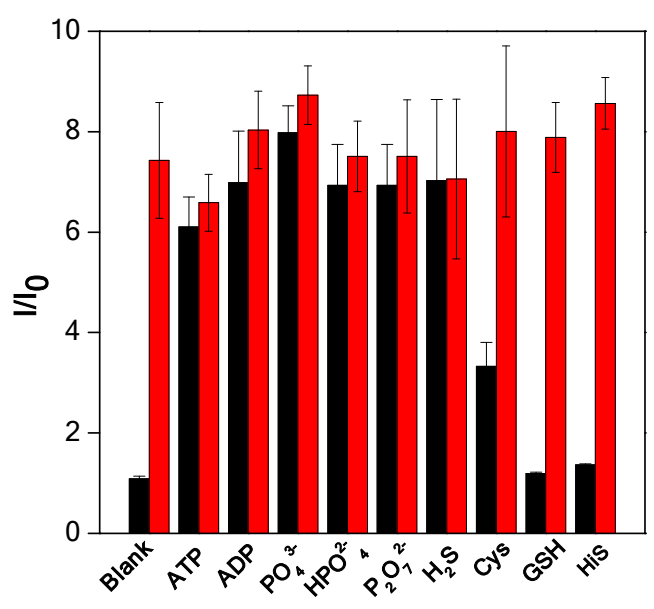

Fig. S9 Selectivity and anti-interference studies of the nanoprobe towards different species with the concentrations up to $1 \mathrm{mM}$. $\mathrm{I}_{0}$ and I are the intensities of the nanoprobe before and after additions of phosphate ions.

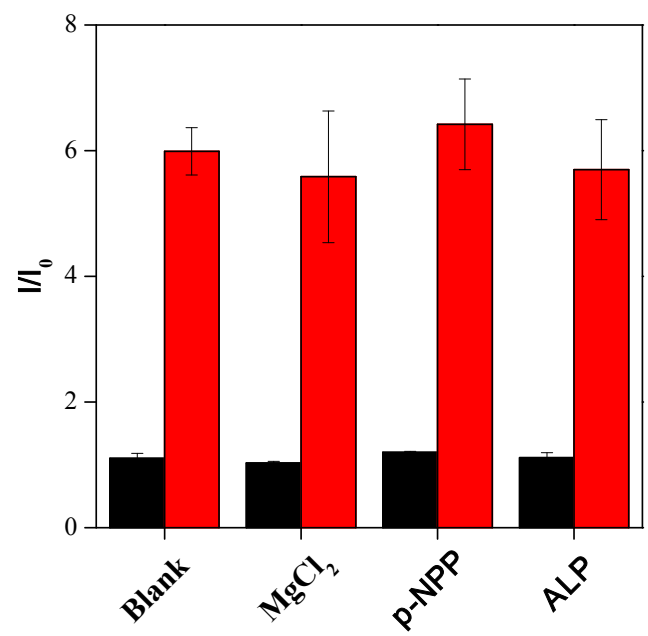

Fig. S10 Luminescence enhancement of the nanoprobe after additions of different substrates of the enzymatic catalysis reaction (black), and upon co-additions of the substrates and the products of ALP catalysis reaction (red). 


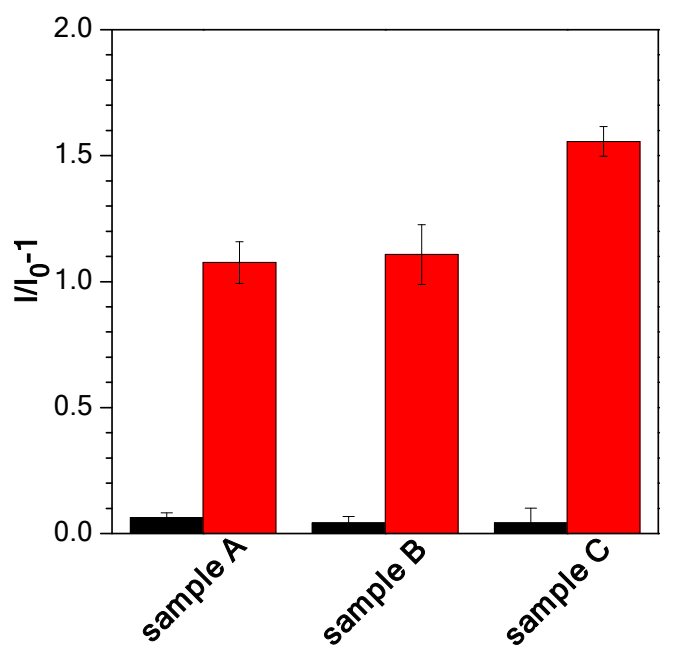

Fig. S11 Luminescence enhancement efficiency $\left(\mathrm{I} / \mathrm{I}_{0}-1\right)$ of the nanoprobe after additions of different serum sample (black), and upon additions of the enzymatic reaction products of different serum sample with p-NPP (red).

Table S1. Practical detection of ALP activity in human serum samples.

\begin{tabular}{ccccccccc}
\hline \begin{tabular}{c} 
Sample $\begin{array}{c}\text { ho } \\
\text { No. }\end{array}$ \\
\cline { 2 - 9 }
\end{tabular} & \multicolumn{3}{c}{ human serum samples(U/L) } & \multicolumn{4}{c}{$\begin{array}{c}\text { human serum samples spiked } \\
\text { with 10 U/L ALP }\end{array}$} \\
\cline { 2 - 9 } & ELISA & This & RSD & Recovery & ELISA & This & RSD & Recovery \\
method & work & $(\%, \mathrm{n}=3)$ & $(\%, \mathrm{n}=3)$ & method & work & $(\%, \mathrm{n}=3)$ & $(\%, \mathrm{n}=3)$ \\
\hline A & 84.75 & 90.82 & 3.980 & 107.1 & 94.75 & 99.94 & 6.771 & 105.5 \\
B & 97.66 & 93.21 & 5.644 & 95.44 & 107.7 & 101.5 & 3.021 & 94.24 \\
C & 130.6 & 127.2 & 2.296 & 97.36 & 140.6 & 138.1 & 6.317 & 98.22 \\
\hline
\end{tabular}


Table S2. An overview on recently studies on the detection of ALP activities, including fluorometry, UV-vis, electrochemisty, and SERS-based methods. The concentration of $1 \mathrm{nM}$ ALP is estimated to be $\sim 3 \mathrm{U} / \mathrm{L}$ according to reference [2].

\begin{tabular}{|c|c|c|c|c|c|}
\hline Material & Method & Detection conditions & $\begin{array}{c}\text { Linearity } \\
(\mathbf{U} / \mathbf{L}) \\
\end{array}$ & $\begin{array}{c}\text { LOD } \\
(\mathrm{U} / \mathrm{L}) \\
\end{array}$ & Ref. \\
\hline CdS QDs & $\begin{array}{l}\text { Fluorogenic } \\
\text { Immunoassay }\end{array}$ & $\begin{array}{c}\text { Tris- } \mathrm{HCl}(50 \mathrm{mM}, \mathrm{pH} 9.8 \\
\left.0.5 \mathrm{mM} \mathrm{MgCl}_{2}\right), 37^{\circ} \mathrm{C}, 90 \mathrm{~min}\end{array}$ & $0-50$ & 0.5 & [1] \\
\hline $\begin{array}{c}\text { Copper } \\
\text { nanoparticles } \\
\text { (CuNPs) }\end{array}$ & $\begin{array}{c}\text { Fluorescent } \\
\text { label-free turn-on } \\
\text { strategy }\end{array}$ & $\begin{array}{c}\text { Tris- } \mathrm{HCl}(10 \mathrm{mM}, \mathrm{pH} 7.4, \\
100 \mathrm{mM} \mathrm{NaCl}), 37^{\circ} \mathrm{C}, 60 \mathrm{~min}\end{array}$ & $0.3-7.5$ & 0.3 & {$[2]$} \\
\hline $\begin{array}{l}\text { Calcein-Ce }^{3+} \\
\text { complex. }\end{array}$ & Fluorescence ELISA & $\begin{array}{l}\text { Tris- } \mathrm{HCl}(50 \mathrm{mM}, \mathrm{pH} 9.0), \\
37{ }^{\circ} \mathrm{C}, 30 \mathrm{~min}\end{array}$ & $0.1-1.2$ & 0.023 & {$[3]$} \\
\hline $\begin{array}{l}\text { Organic dye } \\
\text { (NIR-probes) }\end{array}$ & Fluorescence & $\begin{array}{c}\text { Tris- } \mathrm{HCl}(10 \mathrm{mM}, \mathrm{pH} 7.4), \\
\text { RT, 2min }\end{array}$ & l & $0.01-1$ & {$[4]$} \\
\hline $\begin{array}{l}\text { N-doped carbon } \\
\text { dots }\end{array}$ & Fluorescence & $\begin{array}{c}\text { Tris- } \mathrm{HCl}\left(0.1 \mu \mathrm{M} \mathrm{MgSO}_{4},\right. \\
\mathrm{pH} 9.0), 37^{\circ} \mathrm{C}, 30 \mathrm{~min}\end{array}$ & $0.01-25$ & 0.001 & {$[5]$} \\
\hline $\begin{array}{l}\text { Horseradish } \\
\text { peroxidase(HRP) } \\
\text { and } \mathrm{Cu}(\mathrm{II}) \text { ions }\end{array}$ & UV-vis detection & $\begin{array}{c}\mathrm{PBS}(\mathrm{pH} 7.4), \\
37^{\circ} \mathrm{C}, 60 \mathrm{~min}\end{array}$ & $0-120$ & 5.4 & {$[6]$} \\
\hline $\begin{array}{l}\text { Gold Nanoflower } \\
\text { Probe }\end{array}$ & $\begin{array}{c}\text { Localized Surface } \\
\text { Plasmon Resonance } \\
\text { Technique }\end{array}$ & $\begin{array}{c}\text { Tris }\left(\mathrm{pH} 8.5,0.01 \mu \mathrm{M} \mathrm{AgNO}_{3}\right. \\
0.02 \mu \mathrm{M} \text { AAP }) \\
37^{\circ} \mathrm{C}, 30 \mathrm{~min}\end{array}$ & $\begin{array}{l}0.01 \times 10^{-7} \\
-6 \times 10^{-7}\end{array}$ & $3 \times 10^{-8}$ & {$[7]$} \\
\hline $\begin{array}{l}\mathrm{Au} / \text { Graphene oxide } \\
\text { electrode }\end{array}$ & $\begin{array}{c}\text { Electrochemical } \\
\text { detection }\end{array}$ & $37^{\circ} \mathrm{C}, 60 \mathrm{~min}$ & $1-500$ & 0.5 & {$[8]$} \\
\hline $\begin{array}{c}\text { AuNPs/indigo dye } \\
\text { derivative }\end{array}$ & $\begin{array}{c}\text { SERS-based } \\
\text { microfluidic droplet } \\
\text { technique }\end{array}$ & $\begin{array}{l}\text { Tris- } \mathrm{HCl}(\mathrm{pH} 7.4), \\
120 \mathrm{~min}\end{array}$ & l & $3 \times 10^{-6}$ & [9] \\
\hline $\begin{array}{l}\text { Chemiluminescent } \\
\text { substrate (CSPD) }\end{array}$ & Chemiluminescence & $\begin{array}{l}\text { Tris }(25 \mathrm{mM}, \mathrm{pH} 8.0,0.5 \% \\
\text { Triton X-100), RT, 30min }\end{array}$ & $\begin{array}{c}1 \times 10^{-8} \\
-1 \times 10^{-5}\end{array}$ & $1 \times 10^{-8}$ & {$[10]$} \\
\hline $\begin{array}{c}\text { Fluorogenic } \\
\text { substrate AttoPhos }\end{array}$ & $\begin{array}{l}\text { Capillary } \\
\text { electrophoresis with } \\
\text { laser-induced } \\
\text { fluorescence }\end{array}$ & $\begin{array}{c}\text { Diethanolamine }(2.4 \mathrm{M}, \\
\left.\mathrm{pH} 10.0,57 \mu \mathrm{M} \mathrm{MgCl}_{2},\right), \\
24{ }^{\circ} \mathrm{C}, 60 \mathrm{~min}\end{array}$ & $\begin{array}{l}1.38 \times 10^{-6} \\
-0.138\end{array}$ & $4.5 \times 10^{-8}$ & {$[11]$} \\
\hline $\begin{array}{c}\text { CdSe/ZnS Quantum } \\
\text { Dots }\end{array}$ & $\begin{array}{l}\text { Electron transfer } \\
\text { (ET) }\end{array}$ & $\begin{array}{c}\text { Phosphate buffer }(10 \mathrm{mM}, \mathrm{pH} \\
7.5), 90 \mathrm{~min}\end{array}$ & $\begin{array}{l}0.01-0.1 \\
\text { units }\end{array}$ & 0.01 units & {$[12]$} \\
\hline $\begin{array}{l}\text { Composite } \\
\text { tyrosinase biosensor }\end{array}$ & $\begin{array}{l}\text { Electrochemical } \\
\text { determination }\end{array}$ & $\begin{array}{c}\text { Tris- } \mathrm{HCl}(\mathrm{pH} 8.5) \\
\text { RT, } 5 \mathrm{~min}\end{array}$ & $\begin{array}{c}6 \times 10^{-4} \\
-7.5 \times 10^{-2}\end{array}$ & $2.01 \times 10^{-4}$ & [13] \\
\hline $\begin{array}{l}\text { Upconversional } \\
\text { nanoprobe }\end{array}$ & $\begin{array}{l}\text { Upconversion } \\
\text { luminescence }\end{array}$ & $\begin{array}{c}\text { Tris- } \mathrm{HCl}(10 \mathrm{mM}, \mathrm{pH} 9.8,0.5 \\
\left.\mathrm{mM} \mathrm{MgCl}_{2}\right), 37^{\circ} \mathrm{C}, 30 \mathrm{~min}\end{array}$ & $0.001-0.01$ & $5 \times 10^{-4}$ & $\begin{array}{r}\text { This } \\
\text { work }\end{array}$ \\
\hline
\end{tabular}




\section{References:}

1. Malashikhina, N.; Garai-Ibabe, G.; Pavlov, V., Unconventional application of conventional enzymatic substrate: first fluorogenic immunoassay based on enzymatic formation of quantum dots. Anal Chem 2013, 85 (14), 6866-70.

2. Zhang, L.; Zhao, J.; Duan, M.; Zhang, H.; Jiang, J.; Yu, R., Inhibition of dsDNA-templated copper nanoparticles by pyrophosphate as a label-free fluorescent strategy for alkaline phosphatase assay. Anal Chem 2013, 85 (8), 3797-801.

3. Chen, C.; Zhao, J.; Lu, Y.; Sun, J.; Yang, X., Fluorescence Immunoassay Based on the Phosphate-Triggered Fluorescence Turn-on Detection of Alkaline Phosphatase. Anal Chem 2018, 90 (5), 3505-3511.

4. Park, C. S.; Ha, T. H.; Kim, M.; Raja, N.; Yun, H. S.; Sung, M. J.; Kwon, O. S.; Yoon, H.; Lee, C. S., Fast and sensitive near-infrared fluorescent probes for ALP detection and 3d printed calcium phosphate scaffold imaging in vivo. Biosens Bioelectron 2018, 105, 151-158.

5. Li, G.; Fu, H.; Chen, X.; Gong, P.; Chen, G.; Xia, L.; Wang, H.; You, J.; Wu, Y., Facile and Sensitive Fluorescence Sensing of Alkaline Phosphatase Activity with Photoluminescent Carbon Dots Based on Inner Filter Effect. Anal Chem 2016, 88 (5), 2720-6.

6. Shi, D.; Sun, Y.; Lin, L.; Shi, C.; Wang, G.; Zhang, X., Naked-eye sensitive detection of alkaline phosphatase (ALP) and pyrophosphate (PPi) based on a horseradish peroxidase catalytic colorimetric system with $\mathrm{Cu}(\mathrm{ii})$. Analyst 2016, 141 (19), 5549-54.

7. Wang, K.; Jiang, L.; Zhang, F.; Wei, Y.; Wang, K.; Wang, H.; Qi, Z.; Liu, S., Strategy for In Situ Imaging of Cellular Alkaline Phosphatase Activity Using Gold Nanoflower Probe and Localized Surface Plasmon Resonance Technique. Anal Chem 2018.

8. Shen, C.; Li, X.; Rasooly, A.; Guo, L.; Zhang, K.; Yang, M., A single electrochemical biosensor for detecting the activity and inhibition of both protein kinase and alkaline phosphatase based on phosphate ions induced deposition of redox precipitates. Biosens Bioelectron 2016, 85, 220-225.

9. Sun, D.; Cao, F.; Cong, L.; Xu, W.; Chen, Q.; Shi, W.; Xu, S., Cellular heterogeneity identified by single-cell alkaline phosphatase (ALP) via a SERRS-microfluidic droplet platform. Lab on a chip 2019, 19 (2), 335-342.

10. Blum, J. S.; Li, R. H.; Mikos, A. G.; Barry, M. A., An optimized method for the chemiluminescent detection of alkaline phosphatase levels during osteodifferentiation by bone morphogenetic protein 2. Journal of Cellular Biochemistry 2001, 80(4),532-537.

11. Craig, D. B.; Wong, J. C. Y.; Dovichi, N. J., Detection of attomolar concentrations of alkalinephosphatase by capillary electrophoresis usinglaser-induced fluorescence detection. Anal Chem 1996, 68(4), 697-700.

12. Freeman, R.; Finder, T.; Gill, R. , \& Willner, I., Probing protein kinase (CK2) and alkaline phosphatase with CdSe/ZnS Quantum Dots. Nano Letters 2010, 10(6), 2192-2196.

13. Serra, B.; M.D. Morales, Reviejo, A. J.; Hall, E. H.; J.M. Pingarrón., Rapid and highly sensitive electrochemical determination of alkaline phosphatase using a composite tyrosinase biosensor. Analytical Biochemistry 2005, 336(2), 289-294. 